\title{
COMMENTS
}

\section{Secondary Boycotts and the First Amendment}

Section 8(b)(4)(ii)(B) of the National Labor Relations Act (NLRA) ${ }^{1}$ makes it an unfair labor practice for a union to "threaten, coerce, or restrain any person" with the object of requiring that person to cease dealing with another. ${ }^{2}$ In $N L R B v$. Retail Store Employees Union Local 1001 (Safeco), ${ }^{3}$ the Supreme Court held that this section proscribes union picketing designed to influence consumers to boycott a struck product whenever such picketing "reasonably can be expected to threaten [the picketed retailer] with ruin or substantial loss." Although the Court noted in passing that peaceful picketing is entitled to some first amendment protection, the Court found it "well-established" that Congress had constitutional power to prohibit "picketing that predictably encourages consumers to boycott a secondary business."

Recent commentators have argued that the "ruin or substan-

129 U.S.C. \& 158(b)(4)(ii)(B) (1982).

2 The section reads in pertinent part:

(b) It shall be an unfair labor practice for a labor organization or its agents-

…

(4) ... (ii) to threaten, coerce, or restrain any person engaged in commerce or in an industry affecting commerce, where in either case an object thereof is-

(B) forcing or requiring any person to cease using, selling, handling, transporting, or otherwise dealing in the products of any other producer, processor, or manufacturer, or to cease doing business with any other person, . . . Provided, That nothing contained in this clause (B) shall be construed to make unlawful . . . any primary strike or primary picketing; ....

... Provided further, That . . nothing contained in [this] paragraph shall be construed to prohibit publicity, other than picketing, for the purpose of truthfully advising the public, including consumers and members of a labor organization, that a product or products are produced by an employer with whom the labor organization has a primary dispute and are distributed by another employer . . . .

3447 U.S. 607 (1980).

- Id. at 614.

Id. at 616. 
tial loss" test of Safeco is premised on an invalid distinction between labor-related consumer picketing and other forms of speech that are constitutionally protected. ${ }^{6}$ These criticisms have assumed particular force in light of the Court's subsequent application of a more protective test for political secondary boycotts outside the labor context. ${ }^{7}$ This comment argues that differing tests for labor and political secondary boycotts are undesirable in that contemporary first amendment doctrine provides a consistent framework for analyzing all secondary boycotts. The comment initially examines the basic structure of secondary boycotts and the courts' treatments of such boycotts under the first amendment. The comment then delineates a first amendment framework that requires courts faced with a secondary boycott case to engage in a two-step analysis. First, a court must ask whether the activities of those individuals advocating the boycott affect the advocate's listeners through persuasion or through coercion. If the activities are coercive, the boycott is unprotected. If the activities are persuasive, a court must proceed to the second step of the analysis, and determine whether there are substantial state interests sufficient to support incidental restrictions on the speech elements of the boycott under United States v. O'Brien. ${ }^{8}$

Using this framework, the comment examines the state interests in regulating both primary and secondary boycotts, and con-

- See, e.g., Note, Peaceful Labor Picketing and the First Amendment, 82 Colum. L. REv. 1469, 1497 (1982) [hereinafter cited as Note, Peaceful Labor Picketing] (first amendment doctrines applied to labor picketing are sui generis and designed to protect business property interests); Note, Labor Picketing and Commercial Speech: Free Enterprise Values in the Doctrine of Free Speech, 91 YALE L.J. 938, 939 (1982) [hereinafter cited as Note, Labor Picketing and Commercial Speech] (disguised economic policy judgments underlie Court's inconsistent first amendment treatment of labor picketing and commercial speech); see also Note, Secondary Consumer Picketing, Statutory Interpretation and the First Amendment, 81 Mich. L. REv. 1817, 1821 (1983) [hereinafter cited as Note, Secondary Consumer Picketing] (arguing that Safeco test fails to assess realistically the purposes and impact of secondary consumer picketing).

7 Compare NAACP v. Claiborme Hardware Co., 458 U.S. 886 (1982) (political boycott of white merchants by black citizens to compel legislative change held constitutionally protected), with International Longshoremen's Ass'n v. 'Allied Int'l, Inc., 456 U.S. 212, 226 (1982) (secondary boycott by labor union not protected activity). The Court in Claiborne Hardware briefly alluded to the distinction: "While States have broad power to regulate economic activity, we do not find a comparable right to prohibit peaceful political activity such as that found in the boycott in this case." 458 U.S. at 913.

${ }^{8} 391$ U.S. 367 (1968). O'Brien held that draft card burning was not a constitutionally protected activity. In reaching its conclusion, the Court held that government regulation of activities involving both "speech" and "nonspeech" elements may be constitutionally upheld if the regulation furthers a substantial state interest unrelated to the suppression of free expression and if the incidental restriction on freedom of speech is "no greater than is essential to the furtherance of that interest." Id. at 377. 
cludes that the extent to which a secondary party is economically independent of the primary party, or "neutral," is the key consideration in determining whether a state may constitutionally restrict a union's right to engage in secondary picketing. The comment then briefly compares the interests at stake in political and labor boycotts, and concludes that political boycotts are afforded greater protection than labor boycotts because in a political boycott the secondary target-the government's constituency-is always allied, politically, with the primary party, the targeted government.

\section{BACKGROUND}

A boycott may generally be defined as the withholding of social or business intercourse to express disapproval or to apply economic pressure. ${ }^{9}$ In a primary boycott, one party to a dispute, the boycott advocate, exerts economic pressure directly against his opponent in an effort to force the latter to accede to the former's demands. A secondary boycott adds another level of compulsion: to influence the "primary" opponent, the boycott advocate exerts economic or social pressure against persons who deal with the primary party so that they will join the boycott advocate's cause. ${ }^{10}$ In the case of a labor dispute, the employees, usually through their union, may rely on their own economic power to influence the secondary party, ${ }^{11}$ may urge the secondary party's employees to engage in a partial work stoppage, ${ }^{12}$ or may appeal to customers of the secon-

- Webstzr's Third New Internationax Dictionary 264 (P. Gove ed. 1961).

10 Learned Hand provided one of the best definitions of a secondary boycott in International Bhd. of Elec. Workers Local 501 v. NLRB, 181 F.2d 34, 37 (2d Cir. 1950), aff'd, 341 U.S. 694 (1951):

The gravamen of a secondary boycott is that its sanctions bear, not upon the employer who alone is a party to the dispute, but upon some third party who has no concern in it. Its aim is to compel him to stop business with the employer in the hope that this will induce the employer to give in to his employees' demands.

"See, e.g., International Longshoremen's Ass'n v. Allied Int'l, Inc., 456 U.S. 212 (1982) (longshoremen refused to unload goods belonging to secondary targets, American companies, who dealt with primary target, the Soviet Union); Douds v. Milk Drivers Union Local 584, 154 F. Supp. 222 (S.D.N.Y.) (one group of milk dealers refused to bottle milk for another group of dealers who would not enforce "hot cargo" agreement against a third group), aff'd, 248 F.2d 534 (2d Cir. 1957).

12 See, e.g., International Bhd. of Elec. Workers Local 501 v. NLRB, 341 U.S. 694 (1951) (electricians' union picketed to encourage employees of carpentry subcontractor to engage in work stoppage, thereby coercing subcontractor to pressure the general contractor to hire union labor); NLRB v. International Bhd. of Teamsters Local 182, 272 F.2d 85 (2d Cir. 1959) (union picketed secondary target's premises in effort to induce target's employees to refuse to handle deliveries from primary employer). 
dary party to cease or curtail their patronage. ${ }^{13}$ This comment focuses primarily on the last of these methods of engaging in a secondary boycott and refers to those who appeal to the secondary target's customers as "boycott advocates."

Secondary boycotts need not be labor-related. Political boycotts, for example, are secondary in nature when an aggrieved political group applies economic pressure against other citizens to secure the latter's aid in petitioning the government to pass new legislation. ${ }^{14}$

In both the political and labor contexts, secondary boycotts typically involve several forms of communicative and noncommunicative behavior. Through picketing, speech, and dissemination of literature, the boycott advocates seek to publicize their dispute with the primary target and to garner public support for their position. ${ }^{15}$ The boycott advocates hope that any consequent public withdrawal of patronage from the secondary target will demonstrate to him the strength of the public's support, and will thereby cause him to boycott the primary party as well. A necessary effect of the public's withdrawal of patronage, however, is an immediate injury to the secondary target, accompanied by the message that "punishment will cease if enough concessions are granted."16

At common law, the term "secondary," as applied to labor boycotts, "operated essentially as a synonym for illegality," since courts treated the pressure brought to bear on the secondary party as coercive. ${ }^{18}$ Courts routinely issued injunctions to bar deliberate

1s See, e.g., NLRB v. Retail Store Employees Union Local 1001 (Safeco), 447 U.S. 607 (1980) (employees of primary target, through picketing, urged secondary target's consumers not to buy primary's insurance policies); NLRB v. Fruit \& Vegetable Packers Local 760 (Tree Fruits), 377 U.S. 58 (1964) (employees of primary target urged customers of secondary target, a grocery chain, not to buy apples produced by primary target).

${ }_{14}$ See, e.g., NAACP v. Claiborne Hardware Co., 458 U.S. 886 (1982) (NAACP advocated economic boycott of white merchants by black citizens to pressure merchants, as civic and business leaders, into petitioning the government to pass legislation on issues of racial equality); Missouri v. National Org. for Women, 620 F.2d 1301 (8th Cir.) (National Organization of Women organized convention boycott of states that had not ratified equal rights amendment to secure citizens' aid in pressuring state legislatures to pass the amendment), cert. denied, 449 U.S. 842 (1980).

${ }_{15}$ See Note, Secondary Consumer Picketing, supra note 6, at 1826.

16 F. Hatman, Speech and Law in a Free Socifty 238 (1981).

17 B. Meltzer, Labor Law: Cases, Materials, and Problems 443 (2d ed. 1977); see also Barnard \& Graham, Labor and the Secondary Boycott, 15 WASH. L. Rev. 137, 139 (1940) ("[i]n judicial calculus 'secondary boycott' equals illegality"); Hellerstein, Secondary Boycotts in Labor Disputes, 47 Y ALE L.J. 341, 341-42 (1938) (secondary boycott a "loose and uncertain label used by courts indiscriminately to condemn a wide variety of labor's activities").

18 The Supreme Court, for example, defined "secondary boycott" as 
extensions of labor pressures from the employer with whom the union had a dispute, the primary target, to other employers having business relations with the primary target. ${ }^{19}$

This situation changed dramatically with the New Deal labor legislation of the 1930's. The Norris-LaGuardia Act of $1932^{20}$ forbade the courts to interfere with peaceful labor activity, including secondary boycotts. ${ }^{21}$ Abusive union conduct was not prohibited, and strong unions were able to use secondary boycotts as tools for gaining economic benefits for their members or forcing employers to recognize unions even when they lacked sufficient employee support for legally mandated recognition. ${ }^{22}$

In 1947, Congress passed the Taft-Hartley Act, ${ }^{28}$ which gave the National Labor Relations Board jurisdiction to enjoin unfair labor practices by unions as well as employers. ${ }^{24}$ Section $8(b)(4)(A)$ of the Taft-Hartley Act amended the NLRA to make it an unfair labor practice for a labor organization to engage in, or to encourage the employees of any employer to engage in, a strike or concerted work stoppage where the object of that strike or work stoppage was to force or require any employer or self-employed person to cease doing business with any other person. ${ }^{25}$ The legislative history

a combination not merely to refrain from dealing with complainant, or to advise or by peaceful means persuade complainant's customers to refrain ("primary boycott"), but to exercise coercive pressure upon such customers . . . to cause them to withhold or withdraw patronage from complainant through fear of loss or damage to themselves should they deal with it.

Duplex Printing Press Co. v. Deering, 254 U.S. 443, 466 (1921); see also Barnard \& Graham, supra note 17, at 140 n.13 (citing cases).

10 B. MrLTZER, supra note 17, at 443.

20 Norris-LaGuardia Act of 1932, ch. 90, 47 Stat. 70 (codified as amended at 29 U.S.C. $\$ \$ 101-115$ (1982)).

11 Id. $\$ 4,47$ Stat. 70 (codified as amended at 29 U.S.C. $\$ 104$ (1982)); see H. NoRTHRUP \& G. BLOOM, GOVERnMenT AND LABOR 24 (1963).

22 R. Dereshingky, A. Berkowitz \& P. Miscimarra, The NLRB and Secondary Boycorrs 3 (rev. ed. 1981).

22 Labor Management Relations Act, 1947, ch. 120, 61 Stat. 136 (codified as amended at 29 U.S.C. $\$ 8141-187(1982))$.

24 29 U.S.C. $\$ 158(\mathrm{~b})$ (1982).

${ }^{26}$ Section $8(b)(4)(A)$ originally read, in pertinent part, as follows:

It shall be an unfair labor practice for a labor organization or its agents-

(4) to engage in, or to induce or encourage the employees of any employer to engage in, a strike or a concerted refusal in the course of their employment to . . . handle or work on any goods, articles, materials, or commodities or to perform any services, where an object thereof is:

(A) forcing or requiring . . . any employer or other person to cease using, selling, handling, transporting, or otherwise dealing in the products of any other producer, processor, or manufacturer, or to cease doing business with any other person. 
makes clear that this provision was intended to outlaw secondary boycotts aimed at the business of third parties "wholly unconcerned" with the disagreement between the union and the primary employer. ${ }^{26}$ In 1959, Congress passed the Landrum-Griffin Act $^{27}$ to close perceived loopholes in section $8(\mathrm{~b})(4)(\mathrm{A}){ }^{28}$ The new secondary boycott provision was incorporated in section $8(\mathrm{~b})(4)(\mathrm{ii})(\mathrm{B}) .^{29}$

\section{Judicial Analysis of Secondary Boycotts Under the Frrst AMENDMENT}

\section{A. Primary Labor Picketing Under the First Amendment}

Constitutional protection was first extended to primary peaceful labor picketing in the 1940 Supreme Court decision of Thornhill $v$. Alabama. ${ }^{30}$ The petitioner in Thornhill had been convicted under an Alabama anti-picketing statute that made it a misdemeanor to loiter or picket the worksite of another in order to induce third parties to withhold their business. ${ }^{31}$ The Court held the statute invalid on its face as a violation of the right of free speech. After noting that "[f]ree discussion concerning the conditions in industry and the causes of labor disputes [is] indispensable to the effective and intelligent use of the processes of popular government to shape the destiny of modern industrial society,"32 the Court ruled that Alabama could not enjoin labor picketing except "where the clear danger of substantive evils arises under circumstances affording no opportunity to test the merits of ideas by competition for acceptance in the market of public opinion." ${ }^{\text {s3 }}$

Id. $\S 8(\mathrm{~b})(4)(\mathrm{A})$ (codified as amended at 29 U.S.C. § 158(b)(4)(ii)(B) (1982)).

${ }_{28} 93$ Cong. REc. 4198 (statement of Sen. Taft), reprinted in 2 NLRB, Legistative History of the Labor Management Reiations Act, 1947, at 1106 (1948).

${ }^{27}$ Labor-Management Reporting and Disclosure Act of 1959 (Landrum-Griffin Act), Pub. L. No. 86-257, 73 Stat. 519 (codified as amended at 29 U.S.C. $\$ \S 153,158-160,164,186$, 187, 401-531 (1982)).

${ }^{28}$ See National Woodwork Mfrs. Ass'n v. NLRB, 386 U.S. 612, 633 (1967) ("The Landrum-Griffin Act amendments in 1959 were adopted only to close various loopholes in the application of $\S 8(\mathrm{~b})(4)(\mathrm{A})$ which had been exposed in Board and court decisions.").

${ }^{20} 29$ U.S.C. $\$ 8(\mathrm{~b})(4)(\mathrm{ii})(\mathrm{B})(1982)$, quoted in pertinent part supra note 2.

so 310 U.S. 88 (1940).

31 Id. at 91.

s2 Id. at 103.

ss Id. at 104-05. The Court's language suggests the "clear and present danger" test for protection of speech that evolved from Justice Holmes's famous opinion in Schenck v. United States, 249 U.S. 47, 52 (1919). Cf. Whitney v. California, 274 U.S. 357, 375, 377 (1927) (Brandeis, J., concurring) ("[D]iscussion affords ordinarily adequate protection against the dissemination of noxious doctrine . . . . If there be time to expose through discussion the falsehood and fallacies, to avert the evil by the processes of education, the remedy to be applied is more speech, not enforced silence. Only an emergency can justify re- 
Thornhill established that state power "to set the limits of permissible contest open to industrial combatants" would be subjected to constitutional scrutiny whenever "the effective exercise of the right to discuss freely industrial relations" might be impaired. ${ }^{34}$ One year later, in $A F L v$. Swing, ${ }^{35}$ the Court relied on Thornhill to hold that a state could not bar workers from picketing a non-union employer solely on the ground that the employer's own employees were not parties to the dispute. The Court's broad language suggested that secondary, as well as primary, picketing merited constitutional protection:

The interdependence of economic interest of all engaged in the same industry has become a commonplace. The right of free communication cannot therefore be mutilated by denying it to workers, in a dispute with an employer, even though they are not in his employ. Communication by such employees of the facts of a dispute, deemed by them to be relevant to their interests, can no more be barred because of concern for the economic interests against which they are seeking to enlist public opinion than could the utterance protected in Thornhill's case. ${ }^{36}$

The broad first amendment protection of picketing recognized in Thornhill and Swing was soon restricted. In Giboney v. Empire Storage \& Ice Co., ${ }^{37}$ a union that represented retail ice peddlers picketed a wholesale ice dealer, seeking to obtain an agreement by the dealer not to sell to non-union peddlers. ${ }^{38}$ The Missouri courts, finding that such an agreement would constitute a conspiracy in restraint of trade, enjoined the picketing. ${ }^{39}$ The Supreme Court rejected the union's claim that the injunction was in violation of the first amendment, and found Thornhill inapplicable where the picketing was part of a "single and integrated course of conduct .. . in violation of a valid criminal statute." 40 The Court suggested that picketing could not be separated into illegal and legal components when its "sole, unlawful immediate objective" was to force

pressions."). For a recent discussion of the evolution of the "clear and present danger" test, see Rabban, The Emergence of Modern First Amendment Doctrine, 50 U. CHI. L. REv. 1207 (1983).
310 U.S. at 104.
ss 312 U.S. 321 (1941).
36 Id. at 326 (citations omitted).
3736 U.S. 490 (1949).
ss Id. at 492.
3s Id. at 494 .
10 Id. at 498 . 
the wholesaler to acquiesce in a restraint of trade. ${ }^{41}$

In several subsequent cases, the Court generalized the "integrated course of conduct" rationale announced in Giboney and permitted states to prohibit any picketing that had an "unlawful objective"42 or was designed to induce action "counter to valid state policy."4s The Court repeatedly emphasized that peaceful picketing "involved more than just communication of ideas and could not be immune from all state regulation."44 Moreover, the Court implied that picketing necessarily involved coercive elements "irrespective of the nature of the ideas which are being disseminated."45 Despite the admixture of notions of "unlawful objective," "valid state policy," and inherent coerciveness, it is clear that the Court's post-Giboney cases represented a relaxation of the "clear danger" standard of Thornhill" and gave substantially greater latitude to state and federal prohibitions on picketing. The Court upheld state injunctions against picketing whose goals conflicted with such state policies as nondiscrimination in hiring, ${ }^{47}$ promotion of self-employment, ${ }^{48}$ freedom to hire non-union employees, ${ }^{49}$ and the prevention of a union's coercion of employer support for that union in a representation election. ${ }^{50}$ Because the

4 Id. at 502.

43 See Building Serv. Employees Union Int'l Local 262 v. Gazzam, 339 U.S. 532, 539 (1950) ("unlawful objective" held to be an adequate basis for enjoining picketing); see also International Bhd. of Teamsters Local 309 v. Hanke, 339 U.S. 470, 478-79 (1950) ("[W]e cannot conclude that [the state of] Washington, in holding the picketing in these cases to be for an unlawful object, has struck a balance so inconsistent with rooted traditions of a free people that it must be found an unconstitutional choice.").

4 International Bhd. of Teamsters Local 695 v. Vogt, Inc., 354 U.S. 284, 291 (1957) ("The implied reassessments of the broad language of the Thornhill case were finally generalized in a series of cases sustaining injunctions against peaceful picketing . . . when such picketing was counter to valid state policy in a domain open to state regulation.").

44 Id. at 289. See also Bakery Drivers Local 802 v. Wohl, 315 U.S. 769, 776-77 (1942); Carpenters Union v. Ritter's Cafe, 315 U.S. 722, 725-28 (1941).

4s Bakery \& Pastry Drivers Local 802 v. Wohl, 315 U.S. 769, 776 (1942) (Douglas, J., concurring); see also Hughes v. Superior Court, 339 U.S. 460, 468 (1950) (referring to "the compulsive features inherent in picketing, beyond the aspect of mere communication as an appeal to reason").

46 See supra note 33 and accompanying text.

47 Hughes v. Superior Court, 339 U.S. 460, 468 (1950) (picketing to compel grocery store owner to hire black clerks held to violate state anti-discrimination policy and therefore may be enjoined).

48 International Bhd. of Teamsters Local 309 v. Hanke, 339 U.S. 470, 480 (1950) (picketing to compel sole owner-operator to open a union shop may be enjoined).

49 Local 10, United Ass'n of Journeymen Plumbers v. Graham, 345 U.S. 192, 200-01 (1953) (picketing to enforce union shop may be enjoined since contrary to state right-towork law).

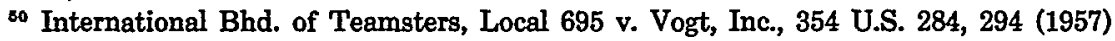
(upholding injunction of picketing designed "to coerce the employer to put pressure on his 
Court consistently deferred to state courts' articulations of their own state's public policy, ${ }^{\text {b1 }}$ the states were in effect left free to enjoin all peaceful picketing "by the simple device of declaring union objectives contrary to public policy."

\section{B. Section 8(b)(4)(ii)(B) and the First Amendment}

The language of section $8(\mathrm{~b})(4)(\mathrm{ii})(\mathrm{B})$ does not forbid all secondary picketing. ${ }^{53}$ Rather, the statute makes it unlawful for a union to "threaten, coerce or restrain any person" with the object of requiring him "to cease doing business with any other person." Limiting provisions make clear that the clause does not proscribe otherwise lawful primary picketing ${ }^{\mathrm{s5}}$ and does not reach "publicity, other than picketing" except in limited circumstances. ${ }^{56}$ As the au-

employees to join the union, in violation of the declared policy of the state"); Building Serv. Employees Int'l Union Local 262 v. Gazzam, 339 U.S. 532, 539 (1950) (upholding injunction of picketing whose objective was to secure "coercion by the employer of the employees' selection of a bargaining representative").

s1 See International Bhd. of Teamsters Local 695 v. Vogt, Inc. 354 U.S. 284, 296 (1957) (Douglas, J., dissenting) (criticizing the Court for letting state courts' determinations of illegality be conclusive); International Bhd. of Teamsters Local 309 v. Hanke, 339 U.S. 470, 478-79 (1950) (deferring to state court view that picketing to compel compliance with demand for a union shop has an unlawful objective); Building Serv. Employees Int'l Union Local 262 v. Gazzam, 339 U.S. at 532, 540 (1950) (whether union picketing to further objectives in violation of state policy may be prohibited does not depend on whether the state provides criminal sanctions to promote the policy).

s2 Fraenkel, Peaceful Picketing-Constitutionally Protected?, 99 U. PA. L. REv. 1, 12 (1950).

ss In Local 1976, United Bhd. of Carpenters v. NLRB, 357 U.S. 93, 98 (1958), the Court stated:

Whatever may have been said in Congress preceding the passage of the Taft-Hartley Act concerning the evil of all forms of "secondary boycotts" and the desirability of outlawing them, it is clear that no such sweeping prohibition was in fact enacted in $\S 8(\mathrm{~b})(4)(\mathrm{A})$ [the precursor to current $\S 8(\mathrm{~b})(4)(\mathrm{ii})(\mathrm{B})$ ]. The section does not speak generally of secondary boycotts. It describes and condemns specific union conduct directed to specific objectives.

See also NLRB v. Fruit \& Vegetable Packers, Local 760 (Tree Fruits), 377 U.S. 58, 62-63 (1964) (reaching the same conclusion with regard to the section (now renumbered \$ 8(b)(4)(ii)(B)) after its amendment by the Landrum-Griffin Act, Pub. L. No. 86-257, $\S 704$ (a), 73 Stat. 519, 542-43 (1959) (codified as amended at 29 U.S.C. $\$ 158(b)(4)(\mathrm{ii})(\mathrm{B})$ (1982)).

st NLRA § 8(b)(4)(ii)(B), 29 U.S.C. § 158(b)(4)(ii)(B) (1982).

ss Id. " "[N]othing contained in this clause (B) shall be construed to make unlawful, where not otherwise unlawful, any primary strike or primary picketing.")

ss NLRA § 8(b), 29 U.S.C. § 158(b) (1982) ("[N]othing contained in [paragraph 4] shall be construed to prohibit publicity, other than picketing, for the purpose of truthfully advising the public, including consumers and members of a labor organization, that a product or products are produced by an employer with whom the labor organization has a primary dispute and are distributed by another employer, as long as such publicity does not have an effect of inducing any individual employed by any person other than the primary employer 
thors of one recent commentary have noted, section 8(b)(4)(ii)(B) "was written with the constitutional distinctions between picketing and publicity in mind."

In NLRB v. Fruit \& Vegetable Packers Local 760 (Tree Fruits), ${ }^{58}$ the Supreme Court relied on both congressional policy and the constitutional clear statement doctrine ${ }^{59}$ to hold that section $8(\mathrm{~b})(4)$ (ii)(B) did not condemn secondary picketing of retail groceries that was directed solely at persuading customers not to purchase apples packed by non-union firms. The Court noted that Congress had consistently refused to prohibit peaceful picketing except where necessary to prevent "clearly identified abuses" of such picketing, ${ }^{60}$ and had expressed its concern that a "broad ban against peaceful picketing might collide with the guarantees of the First Amendment."61 Accordingly, the Court rejected the view that Congress had determined all peaceful picketing at secondary sites to be "necessarily" coercive within the meaning of the Act. ${ }^{62}$

Tree Fruits drew a sharp distinction between picketing "directed only at the struck product"6s and picketing intended "to shut off all trade with the secondary employer unless he aids the union in its [primary] dispute." ${ }^{\prime 64}$ In NLRB v. Retail Store Employees Union, Local 1001 (Safeco), ${ }^{65}$ the Supreme Court modified this distinction and held that secondary picketing directed solely at the struck product nonetheless violates section 8(b)(4)(ii)(B) where it "reasonably can be expected to threaten neutral parties with ruin or substantial loss." afforded to secondary picketing under Tree Fruits to situations

in the course of his employment to refuse to pick up, deliver, or transport any goods, or not to perform any services, at the establishment of the employer engaged in such distribution.").

${ }^{67}$ R. Dereshinsky, A. Berkowitz \& P. Miscimarra, supta note 22, at 231.

88 377 U.S. 58 (1964).

BO Under the "clear statement" model of statutory interpretation, the Court will interpret narrowly all legislation or grants of authority that curtail constitutionally protected rights so as to preserve the legislation's constitutionality. See Kent v. Dulles, 357 U.S. 116, 129 (1958); Note, Intent, Clear Statements and the Common Law: Statutory Interpretation in the Supreme Court, 95 HaRv. L. REv. 892, 908-10 (1982). This principle was reflected in the reluctance of the Tree Fruits Court to "ascribe" to Congress an intent to proscribe all secondary site picketing given that such a broad ban "might collide with the guarantees of the First Amendment." 377 U.S. at 63.

${ }^{60} I d$. at 67 ; see also id. at 62-63.

61 Id. at 63 .

62 Id. at 64 .

os Id. at 65 .

as Id. at 70 .

es 447 U.S. 607 (1980).

${ }^{68}$ Id. at 614. 
where the picketed product is but one among many comprising the secondary target's trade. ${ }^{67}$ Four of the justices on the Safeco Court summarily dismissed any first amendment objections, noting that union picketing that "predictably encourages consumers to boycott a secondary business" necessarily coerces the secondary business to align with the union, and therefore may be constitutionally restricted on the basis of its unlawful objectives. ${ }^{68}$

\section{Political Secondary Boycotts}

In NAACP v. Claiborne Hardware Co., ${ }^{68}$ a unanimous Court indicated that secondary boycotts to achieve governmental change, unlike secondary boycotts for economic objectives in a labor context, are entitled to broad first amendment protection. ${ }^{70}$ Claiborne Hardware concerned a boycott of white merchants by black citizens who sought racial equality in economic and political affairs. The Mississippi Supreme Court, finding that some of the boycott advocates had used force, violence, and threats to promote the boycott, held the entire boycott unlawful and the NAACP, its principal organizer, liable for all lost earnings incurred by the merchants due to the boycott. ${ }^{71}$ The Supreme Court reversed. Reasoning that the boycott involved constitutionally protected rights of speech, assembly, association, and petition, the Court held that "[t]he right of the [s]tates to regulate economic activity could not justify a complete prohibition against [such] a non-violent, politically motivated boycott."72 The Court acknowledged that any vio-

67 Id. at 613. For an argument that this was indeed Congress's intent, see Comment, Consumer Picketing and the Single-Product Secondary Employer, 47 U. CHI. L. REv. 112, 120-24 (1979).

as 447 U.S. at 616. The portion of Justice Powell's opinion rejecting the union's first amendment claims was joined only by Chief Justice Burger and Justices Stewart and Rehnquist. Justice Blackmun criticized the majority for its "cursory discussion of . . . difficult First Amendment issues," $i d$. (Blackmun, J., concurring), but nonetheless felt "reluctant to hold unconstitutional Congress' striking of the delicate balance between union freedom of expression and the ability of neutral employers, employees, and consumers to remain free from coerced participation in industrial strife." Id. at 617-18. In a similar vein, Justice Stevens criticized the plurality for glossing over the awkward fact that the regulation of expression at issue in Safeco was "predicated squarely on its content." Id. at 618 (Stevens, J., concurring). Justice Stevens, however, viewed the statutory ban as regulating only the coercive aspect of the picketing, i.e., "only that aspect of the union's efforts to communicate its views that calls for an automatic reponse to a signal, rather than a reasoned response to an idea." Id. at 619.

458 U.S. 886 (1982).

70 Id. at $912-13$.

"See id. at 895 (discussing the state court holding).

72 Id. at 914. 
lent conduct was, of course, unprotected ${ }^{23}$ but stated that the imposition of liability on the NAACP without any finding that it had actually, or even apparently, ratified that conduct would "impermissibly burden" constitutionally protected rights of political association. ${ }^{74}$

The Court's analysis of the boycott in Claiborne Hardware differed from its analysis of labor boycotts in three significant respects. First, the Court rejected any argument that the boycott lost its protected character because it was intended to coerce. ${ }^{75}$ Thus, the Court left little doubt that the Safeco "ruin or substantial loss" test was constitutionally insufficient in the context of political boycotts. Second, by finding the agreement to act in concert to be itself constitutionally protected, ${ }^{76}$ the Court implicitly rejected the notion, familiar in its labor cases, that the essential nature of boycotting or picketing activity imperceptibly shifts from speech to action as the number of participants and their degree of organization increases. ${ }^{77}$ Finally, the Court rejected the claim that the occurrence of violent acts in conjunction with a boycott is sufficient to condemn it unless "fear rather than protected conduct was the dominant force" in the boycott's success. ${ }^{78}$

\section{First Amendment Analysis}

In Claiborne Hardware, the Court gave little justification for

73 Id. at 933 .

74 Id. at 931.

7s Compare id. at 910-11 with International Longshoremen's Ass'n v. Allied Int'l, Inc., 456 U.S. 212, 226 (1982) (summarily noting, in the context of a politically motivated secondary labor boycott, that "conduct designed not to communicate but to coerce merits [little] consideration under the First Amendment").

78 " "[T]he practice of persons sharing common views banding together to achieve a common end is deeply embedded in the American political process.' " 458 U.S. at 907 (quoting Citizens Against Rent Control Coalition for Fair Housing v. Berkeley, 454 U.S. 290, 294 (1981)).

${ }_{77}$ See, for example, the statement of the Court in Gompers v. Bucks Stove \& Range Co., 221 U.S. 418,439 (1911):

[T] he agreement to act in concert when the signal is published, gives the words "Unfair," "We don't patronize," or similar expressions, a force not inhering in the words themselves, and therefore exceeding any possible right of free speech which a single individual might have. Under such circumstances they become what have been called "verbal acts," and as much subject to injunction as the use of any other force whereby property is unlawfully damaged.

See also Safeco, 447 U.S. at 619 (Stevens, J., concurring) (noting that, in the labor context, "the conduct element rather than the particular idea being expressed . . . provides the most persuasive deterrent to third persons about to enter a business establishment" and that that aspect of the picketing makes it subject to restrictive regulations).

${ }^{78}$ Claiborne Hardware, 458 U.S. at 934. 
treating labor and political boycotts separately except by way of a negative inference from its statement that political speech has always "rested on the highest rung of the hierarchy of First Amendment values." Re Recent commentators have argued persuasively, however, that speech on labor issues extends beyond matters of merely commercial interest and involves fundamental public concerns. ${ }^{80}$. As the Court itself noted in Thornhill, "[f]ree discussion concerning the conditions in industry and the causes of labor disputes appears . . . indispensable to the effective and intelligent use of the processes of popular government to shape the destiny of modern industrial society."81 Because secondary consumer boycotts often play a crucial role in disseminating information about labor disputes, ${ }^{82}$ they merit the same first amendment protection as the political boycott in Claiborne Hardware. Building on these conclusions of earlier commentators, this section of the comment attempts to articulate a common framework for both labor and political secondary boycotts.

\section{A. Overview of the Analysis}

As noted earlier, the Supreme Court has developed two primary justifications for state regulation of the right to picket: first, picketing involves coercive effects that are independent of its communicative aspects; ${ }^{83}$ and second, picketing involves conduct as well as speech, and is therefore subject to legislative control. ${ }^{84}$

79 Id. at 913 (quoting Carey v. Brown, 447 U.S. 455, 467 (1980)). In Connick v. Myers, 103 S. Ct. 1684 (1983), the Court reiterated its view that public-issue speech is entitled to special first amendment protection. There the Court held that a public employee could be discharged for circulating a questionnaire on matters not of public interest. The Court made clear, however, that had the employee spoken "as a citizen on matters of public concern," the discharge would have been unlawful:

[t]he First Amendment "was fashioned to assure unfettered interchange of ideas for the bringing about of political and social changes desired by the people." . . . "[S]peech concerning public affairs is more than self-expression; it is the essence of self-government." . . . Accordingly, the Court has frequently reaffirmed that speech on public issues occupies the "highest rung of the heirarchy [sic] of First Amendment values," and is entitled to special protection.

Id. at 1689 (citations omitted).

${ }^{80}$ See, e.g., Note, Peaceful Labor Picketing, supra note 6, at 1486; Note, Labor Picketing and Commercial Speech, supra note 6, at 955.

31310 U.S. at 103.

ss See Note, Secondary Consumer Picketing, supra note 6, at 1826.

ss See supra note 45 and accompanying text.

s4 See supra note 44 and accompanying text; see also NLRB v. Fruit \& Vegetable Packers Local 760 (Tree Fruits), 377 U.S. 58, 77 (1964) (Black, J., concurring) (" 'Picketing' [normally includes] two concepts: (1) patrolling, that is, standing or marching back and forth ... ; [and] (2) speech, that is, arguments, usually on a placard, made to persuade 
Neither of these rationales suffices to support a per se ban on all secondary boycotts that threaten the secondary target with substantial economic loss. In Claiborne Hardware, the fact that the boycott had a substantial economic impact on the boycotted merchants did not render the boycott subject to state prohibition absent further findings that fear of reprisal was the "dominant force" behind public support of the boycott. ${ }^{85}$ Similarly, the mere fact that picketing involves both conduct and speech does not render the first amendment irrelevant. As the Court held in United States $v$. O'Brien, ${ }^{86}$ communicative conduct is protected by the first amendment; state regulation of such conduct is permitted only when it furthers a substantial governmental interest "unrelated to the suppression of free expression" and involves no greater restriction on first amendment rights than is essential to the furtherance of that interest. ${ }^{87}$

Secondary boycotts involve both speech and nonspeech elements, and should therefore be subject to the O'Brien test. Yet proper first amendment analysis of such boycotts requires a preliminary determination of whether the speech element of the boycott is predominantly persuasive or predominantly coercive, for only if it is predominantly persuasive is it entitled to first amendment protection at all. ${ }^{88}$ Boycotts that are predominantly coercive may be regulated freely while those that are predominantly persuasive may, under O'Brien, be regulated only to protect a compelling state interest and only by the least restrictive means necessary to protect that interest. ${ }^{89}$ In the case of most regulation of secondary boycotts, the state's interest is protecting secondary targets from economic loss. ${ }^{.0}$ Thus, both the preliminary determination

other people to take the picketers' side of a controversy. . . . [P]atrolling is, of course, conduct, not speech, and therefore is not directly protected by the First Amendment.").

83458 U.S. at 934. Cf. NLRB v. Retail Store Employees Union Local 1001 (Safeco), 447 U.S. $607,614,616$ (Secondary picketing that "reasonably can be expected to threaten neutral parties with ruin or substantial loss ... spreads labor discord by coercing a neutral party to join the fray" and may therefore be constitutionally prohibited.).

${ }^{83} 391$ U.S. 367 (1968).

s7 Id. at 377 .

${ }^{88}$ See infra notes $91-93$ and accompanying text.

s9 O'Brien, 391 U.S. at 377.

90 See 93 Cong. REc. 4198 (statement of Sen. Taft), reprinted in 2 NLRB, supra note 26, at 1106 (1948) (Secondary boycott statute "makes it unlawful to resort to a secondary boycott to injure the business of a third person who is wholly unconcerned with the agreement between an employer and his employees."); see also Safeco, 447 U.S. at 614-15 (purpose of $\S 8(\mathrm{~b})(4)(\mathrm{ii})(\mathrm{B})$ is to protect secondary party from threat of substantial economic loss); NLRB v. Business Machine and Office Appliance Mechanics Conference Board, Local 459, 228 F.2d 553, 562 (2d Cir. 1955) (Hand, J., concurring) (secondary boycott statute 
and the O'Brien test involve weighing the degree of coercion, verbal and physical or economic, involved in the boycott. Yet the preliminary determination is concerned only with the relationship between the boycott advocates and those members of the public to whom they address their appeal; the O'Brien test examines the economic impact of the boycotters on the secondary party.

\section{B. Preliminary Inquiry: Persuasion or Coercion}

To be protected under the first amendment, the boycott advocates' appeal to their listeners must be persuasive rather than coercive. The distinction is crucial. Persuasive speech has always been accorded the highest first amendment protection on the theory that the free flow of ideas is central to our democratic system of government: "the best test of truth is the power of the thought to get itself accepted in the competition of the market." trast, speech that deprives its listeners of freedom of choice, i.e., coercive speech, distorts the marketplace of ideas by causing listeners to accept an idea not for its "truth" but to avoid some sanction. ${ }^{92}$ Coercive speech also undermines the political process, since a democratic society depends upon the autonomy of those who publicly espouse a point of view and of those who listen.93

Despite the fundamentality of the coercion/persuasion distinction, courts ${ }^{24}$ and commentators ${ }^{95}$ have generally failed to define

designed to insulate secondary employers from economic sanctions that are reasonable between parties to the primary dispute), cert. denied, 351 U.S. 962 (1956).

or Abrams v. United States, 250 U.S. 616, 630 (1919) (Holmes, J., dissenting).

-2 See generally F. Haiman, supra note 16, at 209-16.

is Cf. Richmond Newspapers, Inc. v. Virginia, 448 U.S. 555, 587-88 (1980) (Brennan, J., concurring) (first amendment guarantee of free speech has "a structural role to play in securing and fostering our republican system of self-government" and therefore requires informed, as well as open, public debate) (emphasis in original); Sarbe v. Washington Post Co., 417 U.S. 843, 863 (1974) (Powell, J., dissenting) (The self-government rationale of the first amendment "encompass[es] the receipt of information and ideas as well as the right of free expression.").

" Common law definitions of "coercion" are overwhelmingly conclusory, defining conduct that is "coercive" simply as "wrongful" or "unlawful." See, e.g., Francis Chevrolet Co. v. General Motors Corp., 602 F.2d 227, 229 (8th Cir. 1979) ("coercion . . . implies wrongful demand") (emphasis in original); General Motors Corp. v. Blevins, 144 F. Supp. 381, 394 (D. Colo. 1956) ("coerce' . . . [means] to compel by threat or other wrongful action") (emphasis added); Sears, Roebuck \& Co. v. Devine, 254 S.W.2d 927, 929 (Ky. 1953) ("coercion exists when one is by the unlawful conduct of another induced to do or perform some act under circumstances which deprive him of the exercise of his free will") (emphasis added).

os Both immediately before and shortly after Thornhill was decided, a number of law review articles discussed the common law courts' attempts to grapple with the coercion/ persuasion distinction. See, e.g., Barnard \& Graham, supra note 17, at 139-41 (in relying on the term "coercion" to hold a boycott "illegal," courts have applied a test "which can be and 
the concept of coercion clearly. As noted in one recent book, coercion presents conceptual difficulties for courts because most situations in which human beings make choices involve "a mix of persuasive and coercive elements"; only when our choices have been reduced to "a sharply limited and unpleasant range of choices" will coercion be said to be operating. ${ }^{96}$ Because the degree of any infringement of an actor's free will is necessarily measured against the base line of the actor's rights and privileges under the law, it is not surprising to find that conduct is usually considered coercive, and the listener's free will infringed, ${ }^{97}$ only after a court has concluded that the listener has a legally protectible interest in avoiding the consequences threatened by the "coercing" party. ${ }^{88}$ Coercion, then, is a label used to characterize the outcome of a

is used with impunity to cloak [their] opinions and predilections . . .."); Hellerstein, supra note 17, at 357-59 (in attempting to distinguish between "coercion" and "persuasion" courts have "resorted to a procedure which should provide inviting material for the student of language and symbolism"); Smith, Coercion of Third Parties in Labor Disputes: The Secondary Boycott, 1 LA. L. Rev. 277, 279-80 (1939) ("coercion" of third party to labor dispute distinguished from peaceful persuasion). In the 1950's, a second series of articles addressed the persuasion-coercion distinction. See Jones, Picketing and Coercion: A Jurisprudence of Epithets, 39 VA. L. REv. 1023 (1953) [hereinafter cited as Jones, Jurisprudence of Epithets] (Court has equated picketing with "coercion" by focusing on "empty cash register" of picketed party, rather than on viewer's response); Gregory, Picketing and Coercion: A Defense, 39 VA. L. Rev. 1053 (1953) (states should be allowed to regulate picketing, which is economic coercion "used in the competitive struggle for self-interest and gain"); Jones, Picketing and Coercion: A Reply, 39 VA. L. Rsv. 1063 (1953) (picketing is not synonymous with "coercion"); Gregory, Picketing and Coercion: A Conclusion, 39 VA. L. RBv. 1067 (1953) (picketing results in economic coercion, and should be declared illegal as such).

96 F. Hatman, supra note 16, at 212.

97 Cf. Sears, Roebuck \& Co. v. Devine, 254 S.W.2d 927, 929 (Ky. 1953) ("[C]oercion" exists when one individual induces another "to do or perform some act under circumstances which deprive him of the exercise of his free will.") (emphasis added); Norton v. Michigan State Highway Dep't, 315 Mich. 313, 319-20, 24 N.W.2d 132, 135 (1946) ("Coercion" that invalidates a contract means the "application of such force . . . as to constrain [a party] to do against his will something he would not otherwise have done.") (emphasis added); First State Bank v. Federal Reserve Bank, 174 Minn. 535, 537, 219 N.W. 908, 909 (1928) ("To sustain an action for damages on the ground of coercion, there must be some wrongful or unlawful act, acts or conduct on the part of the defendant sufficient to constrain the plaintiff, against his will, to do or refrain from doing something which he has a legal right to do or refuse to do.") (emphasis added).

${ }^{28}$ See, e.g., Berry Bros. Buick, Inc. v. General Motors Corp., 257 F. Supp. 542, 546 (E.D. Pa. 1966) (reasonable demand by manufacturer on dealer to accept automobiles or parts is not "coercion" within meaning of Automobile Dealers' Act, since manufacturer has right to goad along an inefficient dealer); McKay v. Retail Auto. Salesmen's Local Union 1067, 16 Cal. 2d 311, 321, 106 P.2d 373, 379 (1940) ("[C]oercion" of employer to yield to employees' demands, out of fear that he will otherwise be unable to obtain suitable employees, "is not the kind of coercion of which courts can take notice."); Alfred W. Booth \& Bro. v. Burgess, 72 N.J. Eq. 181, 195, 65 A. 226, 232 (1906) ("Coercion which results . . . from the exercise of the absolute right to refrain from contracting, cannot possibly be a tort, because it violates no legal right."). 
balancing of interests in a given situation, rather than a concept with a precise and independent analytic content. ${ }^{99}$

Because one central concern of the first amendment is to ensure the existence of a free market in ideas, ${ }^{100}$ the preliminary inquiry for determining whether a secondary boycott is predominantly coercive and hence unprotected by the first amendment focuses on the reaction of the listeners to the boycott advocates' message, ${ }^{101}$ and not on the economic vulnerability of the secondary party. At this stage of the analysis, the interests at stake in determining whether the speech is coercive are the listeners' and not the secondary target's. ${ }^{102}$ In a typical secondary boycott, a boycott advocate's message is thrust into the marketplace of ideas, and the boycott's success or lack thereof is linked to the persuasive appeal of the advocate's position to the public generally. Only where the listeners join in the boycott out of fear can the boycott properly be held coercive for the purpose of deciding whether the speech is protected.

Several first amendment decisions outside the boycott context provide a framework for analyzing the coerciveness of the boycott advocates' appeal. In Bridges v. California, ${ }^{103}$ the Court overturned the contempt conviction of a labor leader who had published a statement that enforcement of a judge's decree would result in a statewide strike. The Court held that the message was not suffi-

" Oliver Wendell Holmes's observation in Privilege, Malice \& Intent, 8 HARv. L. Rev. 1 (1894), where he discusses interference with contract, is apposite here. Holmes states that a court's determination that a plaintiff has or lacks an interest is often largely a question of policy, and that judges are

shy of reasoning [on] such grounds. Therefore, decisions for or against [a defendant's] privilege [to inflict injury on the plaintiff], which really can stand only upon [policy] grounds, often are presented as hollow deductions from empty general propositions ... or else are put as if they themselves embodied a postulate for the law and admitted of no further deduction.

Id. at 3. The common law concept of "coercion," as applied to secondary boycotts, falls into the latter category.

${ }^{100}$ See, e.g., Whitney v. California, 274 U.S. 357, 375 (1926) (Brandeis \& Holmes, JJ., concurring) (first amendment doctrine premised on notion that free discussion affords adequate protection against erroneous ideas); Abrams v. United States, 250 U.S. 616, 630 (1919) (Holmes, J., dissenting) (central concern of first amendment is free trade in ideas).

${ }^{101}$ See, e.g., NAACP v. Claiborne Hardware Co., 458 U.S. 886, 894-95, 922 (1982) (rejecting the lower court's finding that "many black persons . . . were forced and compelled against their personal wills to withhold . . . trade" and then finding "ample support in the record" to conclude that most witnesses voluntarily participated in the boycott).

${ }^{102}$ See Note, Labor Picketing and Commercial Speech, supra note 6 at 952 (Court's current illegal objective test fails to draw "the crucial distinction between the economic coercion of the picketed business that may result if the listeners are persuaded by the message, and the coercion of the listeners themselves").

103314 U.S. 252 (1941). 
ciently threatening to have intimidated the state court judge, ${ }^{104}$ and therefore involved no clear and present danger sufficient to justify punishment. ${ }^{105}$ Quoting language from an earlier decision, the Court found nothing in the labor leader's statement "which would have affected a mind of reasonable fortitude." ${ }^{106}$ Similarly, in Chaplinsky $v$. New Hampshire, ${ }^{107}$ the Court, in determining whether or not certain "fighting words" were protected speech, focused on the reaction of the "average addressee" and not on the intent of the speaker. ${ }^{108}$ Finally, in NLRB v. Gissel Packing Co., ${ }^{109}$ the Court took judicial notice of the "economic dependence of . . . employees on their employers"110 in holding that an employer's prediction of plant closing in the event of unionization was a "threat of retaliation based on misrepresentation and coercion, and as such without the protection of the First Amendment."111

Together, Bridges, Chaplinsky, and Gissel Packing suggest that of the three indicia of coercion in action-inducing speech-the intent of the speaker, the actual words spoken, and the reaction of the listeners ${ }^{112}$ - it is the last that is the most important. In the context of secondary boycotts, a test that focuses solely on the intent of the speaker would improperly protect boycotts in which average listeners, misperceiving a boycott advocate's lack of intent to carry out his threats, were led to participate in the boycott solely because they feared sanctions from the boycott advocate if they failed to participate. Conversely, a test that focuses on the boycott advocate's actual words might lead to restricting boycotts in which the speaker's words, taken literally, conveyed a threat but were not so understood by average listeners. The Court's opinion in Claiborne Hardware illustrates the problem. Although one of the boycott leaders had, on at least two occasions, threatened physical vio-

104 Id. at 278 .

10 sd. at 262-63.

${ }^{108}$ Id. at 278 (quoting Toledo Newspaper Co. v. United States, 247 U.S. 402, 425 (1918) (Holmes, J., dissenting)).

107315 U.S. 568 (1942).

108 Id. at 573.

109395 U.S. 575 (1969).

110 Id. at 617 .

11 Id. at 618; see also id. at 619-20 (discussing how employees take hints of plant closings as coercive threats and not honest forecasts).

11 In Watts v. United States, 394 U.S. 705 (1969), the Court focused on all three of these factors in holding that a young man's remark during a political rally that he wanted to get then-President Lyndon Johnson "in [his] sights," id. at 706, was not an unlawful threat on the President's life. The Court noted that the speaker had no intention of implementing his threat, id. at 707-08, that the words themselves were mere political hyperbole, id., and that "the crowd laughed after the statement was made," id. at 707. 
lence for noncompliance with the boycott, ${ }^{113}$ the Court relied in its decision on evidence that those individuals who participated in the boycott did so not out of fear but because they believed in the boycott's underlying purpose. ${ }^{114}$

As in Claiborne, the key question in analyzing the coercive impact of a secondary boycott must be whether "fear rather than protected conduct [is] the dominant force" in the boycott's success. ${ }^{115}$ In the past, commentators have attempted to answer this question by differentiating between "signal picketing," in which a union signals a large scale strike to union members and members of affiliated unions, and "publicity picketing," in which a union seeks to persuade the general public to adopt the union's viewpoint. ${ }^{116}$ Adopting this distinction, courts have held illegal under section $8(\mathrm{~b})(4)(\mathrm{ii})(\mathrm{B})$ those secondary boycotts in which a union's speech is directed not toward the public, but toward other union members. ${ }^{117}$ Underlying this distinction is the notion that appeals to join boycotts, when directed solely at other union members, rely for their success not on persuasion but on the implicit threat that economic sanctions, such as union fines, will be imposed on members who do not toe the union line. ${ }^{118}$

113 On April 19, 1969, Charles Evans "[s]tated that boycott violators would be 'disciplined' by their own people." Two days later he stated, " 'If we catch any of your sons in any of their racist stores, we're gonna break your damn neck." " 458 U.S. at 902.

114 Id. at 904-05 n.37, 922, 923 n.63.

125 Id. at 934 . Fear may be induced by threats that are either verbal or physical, actual or implied. An implied threat, for example, may inhere in conduct or symbols alone.

11 E.g., Cox, Strikes, Picketing and the Constitution, 4 VAND. L. REv. 574, 594 (1951); see also NLRB v. Retail Store Employees Union Local 1001 (Safeco), 447 U.S. 607, 619 (1980) (Stevens, J., concurring) ("The statutory ban in this case affects only that aspect of the union's efforts to communicate its views that calls for an automatic response to a signal, rather than a reasoned response to an idea."); T. Emerson, The System of Frezdom of Expression 445 (1970) ("Labor picketing . . . is applied by closely knit, powerful organizations ... . A labor picket line is thus not so much a rational appeal to persuasion as a signal for the application of immediate and enormous economic leverage.").

${ }_{117}$ See e.g., NLRB v. Local 825, A, B, C, D, Int'l Union of Operating Eng'rs, 659 F.2d 379, 387 (3d Cir. 1981) ("signal picketing" defined as picketing directed to providing "a signal to neutrals that sympathetic action on their part is desired" but its lawfulness left undecided); International Ass'n of Bridge, Structural \& Ornamental Iron Workers Local 433 v. NLRB, 598 F.2d 1154, 1158-60 (9th Cir. 1979) (evidence that boycott advocates spoke with employees of neutral employers in an alleged effort to induce them to strike constitutes substantial evidence that "signal picketing" had occurred); Hirsch v. Building \& Constr. Trades Council, 530 F.2d 298, 304 (3d Cir. 1976) (union's picketing of construction project "designed to appeal to other organized labor groups to exert economic pressure on an employer," rather than to inform or advise the public, proscribed under $\$ 8(\mathrm{~b})(4)(\mathrm{ii})(\mathrm{B})$ ).

13e See Cox, supra note 116, at 594 (discussing the disciplinary economic sanctions facing secondary employee union members who cross a picket line). But see Jones, Jurisprudence of Epithets, supra note 95, at 1043-44 (suggesting that union ability to impose economic sanctions on union members cannot be presumed in all situations). 
While attention to the particular audience is crucial in determining whether appeals to join a boycott carry with them implicit threats, ${ }^{119}$ a per se rule prohibiting labor secondary boycotts that appeal not to the public but to other union members is likely to be overbroad. A secondary boycott that instigates a sympathy strike by the secondary target's employees should not be presumed to be coercive. Nor should the fact that the boycott sparks a "reflexive" rather than reasoned response be determinative of coercion, ${ }^{120}$ since such a response may indicate natural empathy as easily as coerced support. Rather, courts analyzing the coerciveness of a boycott must, as did the Supreme Court in Claiborne Hardware, look carefully at the context of the boycott, the actual words of inducement, and, above all, the reaction of the listeners in determining whether the boycott advocates have used fear or persuasion to garner support for their cause.

\section{Balancing the Union's Interest in Free Speech Against the Employer's Interest in Freedom from Economic Pressure}

Once it has been determined that the speech aspect of a boycott is predominantly persuasive, the boycotters' interest in expressing their views through withdrawing patronage from a primary or secondary party must be weighed against that party's interest in remaining free from economic pressure. In the past, courts have categorically equated this pressure with coercion and, as a result, have denied first amendment protection to secondary boycotts. ${ }^{121}$ This practice, however, confuses coercion of the boycott advocate's "listeners" with the economic pressure that those who heed the advocate's appeal and join the boycott subsequently exert upon the secondary party. ${ }^{122}$ Assuming that the boycott advocates predominantly persuade rather than coerce their listeners, and so do not deprive them of free will, any subsequent pressure on the secondary party will be coercive only because of the voluntary actions of the listeners. It is analytically inaccurate to equate speech that persuades its listeners to exert economic pressure on

11 For an example of the importance of determining the intended audience, see NLRB v. Gissel Packing Co., 395 U.S. 575, 619-20 (gauging the reactions of employees to determine whether employer's "prediction" of plant closing was an unlawful threat).

${ }_{130}$ See NLRB v. Retail Store Employees Union Local 1001 (Safeco), 447 U.S. 607, 619 (1980) (Stevens, J., concurring) (discussing reflexive nature of response to picketing as a rationale for its regulation).

${ }_{121}$ See, e.g., International Longshoremen's Ass'n v. Allied Int'l, Inc., 456 U.S. 212, 226 (1982).

${ }^{122}$ See supra note 102. 
the secondary target with speech that is itself coercive, and hence per se unprotected. ${ }^{123}$

Past judicial practice is unsound for a second reason. As was noted above, "coercion" is little more than a label used by courts to characterize conduct in which the interests of the coerced party outweigh those of the coercing party. ${ }^{124}$ Where the interests of the coercing party are protected by the first amendment, courts are not free to invent their own calculus for balancing those interests under the guise of deciding whether the conduct in question is coercive: the Supreme Court has already provided that calculus in its decision in United States v. O'Brien.125 The Court in O'Brien held that "when 'speech' and 'nonspeech' elements are combined in the same course of conduct," a governmental regulation of the nonspeech element which incidentally restricts first amendment freedoms may be justified only

if it is within the constitutional power of the Government; if it furthers an important or substantial governmental interest; if the governmental interest is unrelated to the suppression of free expression; and if the incidental restriction on alleged first amendment freedoms is no greater than is essential to the furtherance of that interest. ${ }^{128}$

As noted earlier, all boycotts involve expressive conduct on the part of the boycotters, ${ }^{127}$ and are therefore subject to the $O^{\prime} B r i e n$ test. The government may thus regulate the boycotters' infliction of concerted economic pressure if, but only if, that regulation is the least restrictive means of furthering a substantial state interest that is unrelated to the suppression of free expression. To determine whether and when the government has a substantial interest in protecting the target of a secondary boycott, this section examines first, the nature of the interests of any party who is the target of a boycott, and second, the degree to which the nature or extent of those interests is different in a secondary boycott.

1. Primary Boycotts. Courts have held that a businessman has no legally cognizable interest in preventing his customers from withholding their patronage, ${ }^{128}$ and that an individual not bound

${ }^{123}$ Note, Labor Picketing and Commercial Speech, supra note 6, at 952 (Court fails to draw "crucial distinction" between coercion of picketed business and coercion of listener).

326 See supra notes 94-99 and accompanying text.

125391 U.S. 367 (1968).

128 Id. at 377.

${ }_{127}$ See supra text accompanying notes $15-16,86-87$.

${ }^{128}$ An early statement of the notion that a businessman's interest in his customers' 
by prior contractual obligations generally has a right to cease doing business with another at will. ${ }^{129}$ From this premise it is easy to argue that a boycott by consumers of a particular business should be protected under the first amendment. Any state interest in protecting a retailer's patronage would appear insufficient to satisfy the O'Brien test. Indeed, in Claiborne Hardware, the Court explicitly held that citizens had a first amendment right to induce third parties to withhold patronage for political reasons. ${ }^{130} \mathrm{~A}$ denial of the same protection to citizens who seek to induce third parties not to deal with a boycott target for labor-related reasons would be nothing short of content-based discrimination, an anathema to the values at the core of the first amendment. ${ }^{131}$

Where a boycott advocate seeks not to induce the withholding of patronage by customers but work stoppages by the boycott target's employees, the target's interest in both uninterrupted business operations and unbroken labor contracts may weigh substantially more heavily against the boycott advocate's first amendment interest in the balance mandated by O'Brien. Similarly, secondary picketing might be unprotected when a union, advancing its own organizational or recognitional objectives, pickets a secondary employer primarily to pressure him into boycotting a primary employer who employs nonunion labor or the labor of a different union. ${ }^{132}$ In this situation, the $O^{\prime} B$ rien balance may weigh in favor

continued patronage is legally unprotected may be found in Mogul S.S. Co. v. McGregor, 23 Q.B.D. 598 (1889), aff'd, 1892 A.C. 25, 36-37, where the court held that traders who lost patrons when a group of rival traders reduced its prices to the public had no protected interest in retaining customers, and thus had suffered no legal injury. The Mogul analysis was adopted by Holmes in Privilege, Malice \& Intent, where he suggests that our legal doctrines are based on the economic postulate of free competition, and that under this postulate, American courts have recognized a consumer's privilege, absent malicious intent, both to form and to abstain from forming contracts with another party. Holmes, supra note 99 , at 3.

${ }^{129}$ See United States v. Colgate \& Co., 250 U.S. 300,307 (1919) (holding that the Sherman Act "does not restrict the long recognized right of trader or manufacturer . . . freely to exercise his own independent discretion as to parties with whom he will deal"); Rohm \& Haas Co. v. Dawson Chemical Co., 557 F. Supp. 739, 844 (S.D. Tex. 1983) ("It is a general characteristic of free enterprise that a trader or manufacturer has the right to exercise his discretion in choosing with whom he will conduct business."); McGee v. Collins, 156 La. 291, 305,100 So. 430,435 (1924) ("An individual, regardless of motive, has an absolute right to refuse to deal with another.").

130458 U.S. at 909.

1s1 For a persuasive argument that the Court's distinction between public issues and labor issues in picketing cases constitutes a content-based discrimination, see Note, Labor Picketing and Commercial Speech, supra note 6, at 947-49. Ordinarily, content-based restrictions on freedom of speech are subject to strict judicial scrutiny. See Stone, Content Regulation and the First Amendment, 25 WM. \& MARY L. REv. 189 passim (1983).

13229 U.S.C. $\S 158(\mathrm{~b})(1)$ (1982) suggests this result. Under this statutory provision, a 
of protecting the primary employees' free choice in not unionizing, or in selecting their own bargaining representative without interference.

2. Secondary Boycotts. The state or federal interest in "shielding unoffending employers and others from pressures in controversies not their own"1s3 has frequently been cited to justify state restrictions on secondary boycotts that would be impermissible if imposed on primary boycotts. ${ }^{134}$ Under current law, a union has a legitimate interest in bringing economic pressure to bear against a primary employer with whom it has a dispute, ${ }^{135}$ but may not coerce a "neutral" party into joining the fray through activities that threaten him with "substantial loss." gests that the $O^{\prime} B r i e n$ test, when applied to secondary boycotts, should focus on the definitions of "neutrality" and "substantial loss" to ensure that alleged restrictions on the first amendment freedoms associated with boycotting serve substantial state interests and are no more restrictive than necessary to further those interests. This section argues that the interests of the secondary target, and hence of the state, are a function of both the target's neutrality and the substantiality of its threatened loss: the degree of economic harm a secondary target may suffer before the state's interests are substantial enough to justify incidental restrictions on first amendment freedoms should be determined by the extent to which the target is neutral. ${ }^{137}$

labor union may not "restrain or coerce . . . employees in the exercise" of their associational rights. This section is limited, however, by the proviso in $\$ 158(\mathrm{~b})(7)(\mathrm{C})(1982)$, which states that when organizational or recognitional picketing is "for the purpose of truthfully advising the public . . . that an employer does not employ members of, or have a contract with, a labor organization," the picketing is not illegal unless it interferes with deliveries or services by third parties.

${ }^{133}$ NLRB v. Denver Bldg. \& Constr. Trades Council, 341 U.S. 675, 692 (1951).

136 See, e.g., International Longshoremen's Ass'n v. Allied Int'l, Inc., 456 U.S. 212, 225 (1982) (secondary boycott provision drafted to protect neutral parties from quarrels not their own); Safeco, 447 U.S. 607, 617-18 (1980) (§ 8(b)(4)(ii)(B) represents Congress's " 'striking of the delicate balance between union freedom of expression and the ability of neutral employers, employees and consumers to remain free from coerced participation in industrial strife'").

135 See R. Dereshinsky, A. Berkowitz \& P. Miscimarra, supra note 22, at 1.

${ }^{130}$ Cf. Claiborne Hardware, 458 U.S. at 912 ("Secondary boycotts and picketing by labor unions may be prohibited, as part of 'Congress' striking of the delicate balance between union freedom of expression and the ability of neutral employers, employees, and consumers to remain free from coerced participation in industrial strife." ") (quoting Safeco, 447 U.S. at 617-618 (Blackmun, J., concurring)).

${ }^{137}$ Section $8(\mathrm{~b})(4)(\mathrm{ii})(\mathrm{B})$ seems to have been drafted with such a balancing test in mind. Because $\S 8(\mathrm{~b})(4)$ (ii)(B) permits coercive boycotts of primary targets but only the peaceful publicizing of disputes with the primary target to a secondary target's customers, a 
Because the secondary boycott statute protects only disinterested parties, ${ }^{138}$ the NLRB, the federal judiciary, and state courts have developed various doctrines to sanction secondary boycotts directed at companies that have accepted work that the struck employer has farmed out ${ }^{139}$ or companies that are owned or controlled by the primary employer and are part of an integrated operation. ${ }^{140}$ A secondary target who fits one of these descriptions is not deemed to be neutral to the primary target's labor dispute, but is instead considered an "ally" of the primary target. ${ }^{141}$

Under current law, the "ally" doctrine developed under section $8(\mathrm{~b})(4)(\mathrm{ii})(\mathrm{B})$ protects secondary targets who are economically interdependent with the primary target but are nonetheless neutral to the primary target's labor dispute. ${ }^{142}$ When viewed in conjunction with the "ruin or substantial" loss test of NLRB v. Retail Store Employees Union Local 1001 (Safeco), ${ }^{143}$ this doctrine leads to rather arbitrary results. As discussed earlier, Safeco held that secondary site picketing directed solely at the struck product is coercive within the meaning of section $8(\mathrm{~b})(4)(\mathrm{ii})(\mathrm{B})$ if it threatens the secondary target with "ruin or substantial loss."144 Under this test, the ability of a labor group to publicize its dispute to the consuming public depends ultimately and arbitrarily on the primary target's marketing and distribution methods, and, in particular, on whether the primary target markets its products through nonspecialty stores or through franchises that sell few if any other products. For example, Safeco would permit secondary picketing of a grocery store selling the fruit of the primary target, but not of a fruit stand selling primarily or only such fruit, even if the latter would be a more effective forum for publicizing the primary dis-

court deciding the legality of a boycott of a secondary target that is economically interdependent with the primary target must decide whether the degree of threatened loss to the secondary target predominates over the degree of interdependence with the primary target. If the loss predominates, then the boycott most closely resembles the coercive boycotting of a neutral secondary target, which the statute forbids; if the interdependence predominates, then the boycott more closely resembles a boycott of the primary target, which is permitted.

188 See supra note 26 and accompanying text.

138 See, e.g., Douds v. Metropolitan Fed'n of Architects Local 231, 75 F. Supp. 672, 67677 (S.D.N.Y. 1948). See generally R. Dereshinsky, A. BERKowTtz \& P. MiscimarRa, supra note 22 , at $122-56$.

140 See R. Dereshinsky, A. Berkowitz \& P. Miscimarra, supra note 22, at 156-80.

141 Id. at 121.

142 Id. at $165 \mathrm{n} .149$ (noting that the NLRB "has stated continuously that it will not predicate loss of neutral status on economic interdependency alone, absent common ownership or control").

14447 U.S. 607, 614-15 (1980).

14 See supra text accompanying notes 65-68. 
pute. Similarly, Chrysler employees would be unable to engage in a secondary boycott of Chrysler's independent distributors, since, generally, they sell only Chrysler cars, but employees who aid in producing products generally sold in dime stores would be able to picket secondary retailers. The rights of employees and unions to publicize disputes should not so depend on the vagaries of the primary target's marketing methods.

A better result may be reached by taking the unity of economic interest ${ }^{145}$ between the secondary and primary targets into account in assessing the extent of loss that will justify the state's regulation of the boycott under O'Brien. As noted by the Supreme Court in NLRB v. Fruit \& Vegetable Packers Local 760 (Tree Fruits), ${ }^{146}$ only when the union creates a dispute with the secondary employer that is separate from its dispute with the primary employer do the congressional concerns of section $8(\mathrm{~b})(4)(\mathrm{ii})(\mathrm{B})$ come into play. ${ }^{147}$ The Safeco plurality inferred such a "separate dispute" to exist whenever the economic effect of the secondary picketing "reasonably can be expected" to be coercive. ${ }^{148}$ This conclusion, however, effectively ignores the fact that even primary boycotts, if successful, will induce secondary parties who were economically dependent on the primary party to trade elsewhere. For example, the coercive effects in Safeco would have been no different had the union successfully publicized its dispute through picketing at the primary site.

By merging the concepts of neutrality and substantial loss to proscribe only threats disproportionate to the secondary target's common economic interest with the primary target, the present test would ensure that courts not confuse what are essentially the secondary effects of a primary dispute with an unlawful "secondary" dispute. Such a test would avoid arbitrary results currently possible under $S a f e c o$ and would preserve the O'Brien requirement that incidental restrictions on speech through regulations of ex-

${ }_{145}$ The courts of New York, in interpreting that state's labor laws, have used the term "unity of interest" as a catch phrase in determining when a union "may follow the nonunion goods and seek by peaceful picketing to persuade the consuming public to refrain from purchasing the nonunion product, whether ... at the plant of the manufacturer or at the store of the retailer in the same line of business and in unity of interest with the manufacturer." Goldfinger v. Feintuch, 276 N.Y. 281, 286, 11 N.E.2d 910, 913 (1937); accord Empire Smokes, Inc. v. Finch, 3 A.D.2d 503, 506, 162 N.Y.S.2d 329 (1957).

146377 U.S. 58 (1964).

167 Id. at 72 .

148 Safeco, 447 U.S. at 614. 
pressive conduct be no more restrictive than necessary to serve a substantial state interest.

\section{Secondary Neutrality in Political Boycotts}

In a political secondary boycott, where the boycott advocates put economic pressure on third parties to further their goals of fostering political change, the second level of compulsion is not economic but political. Therefore, the assessment of neutrality that $O$ 'Brien requires in weighing the state interest at stake must focus on whether the primary and secondary targets are in unity of political interest. In a democratic republic, the state or federal legislature (the primary target in a political secondary boycott) is considered the "agent" or alter ego of its constituency (the secondary target). ${ }^{149}$ Under this structural view of government, citizens of a municipality, state, or nation are by definition in unity of political interest with their legislatures and hence will almost never be neutral.

This structural view was implicitly adopted in both Claiborne Hardware and Missouri v. National Organization of Women. ${ }^{180}$ The courts in both cases held the political boycott to be constitutionally protected as a petitioning of the government for a redress of grievances despite the extension of the boycott to secondary targets. In neither case did the court inquire into the individual political views of the merchants against whom the boycott was directed. Instead, the courts implicitly treated the boycott as primary, not secondary, in nature. Both Claiborne Hardware and Missouri v. National Organization of Women thus suggest that citizens of a given political community cannot claim neutrality in relation to their government, and therefore cannot invoke any substantial state interest, overriding the first amendment interests of the political boycotters, to protect themselves from economic harm.

\section{Conclusion}

This comment has argued that current first amendment doctrine provides a comprehensive framework for analyzing all secondary boycott cases. In delineating this framework, the comment

\footnotetext{
149 See The Federalist No. 14, at 100 (J. Madison) (C. Rossiter ed. 1961) ("It is in a democracy that the people meet and exercise the government in person; in a republic they assemble and administer it by their representatives and agents.").

${ }^{150} 620$ F.2d 1301 (8th Cir.), cert. denied, 449 U.S. 842 (1980).
} 
has identified two basic steps for discovering the first amendment status of a given secondary boycott: first, is the boycott advocate's "message" persuasive, and hence protected by the first amendment, or coercive, and hence entirely outside the first amendment's protection; and second, if the boycott advocate's message is persuasive, to what extent is regulation of the boycott nonetheless justified under United States $v$. O'Brien as an incidental restriction on speech necessary to further substantial state interests. The comment has argued that, in answering this second question, the proper analysis under $O^{\prime} B r i e n$ should focus on the extent to which the secondary target shares an economic interest, or, in the case of political boycotts, a political interest, with the primary target. The comment concludes by arguing that, in a democracy, the secondary target in a political secondary boycott almost always will share a political interest with the primary target and thus can almost never claim "neutrality." Thus, the distinctions in the results that the Supreme Court has reached in assessing the legality of labor and political boycotts may be justified under a single framework, rather than viewed as questionable content-based discrimination.

Barbara J. Anderson 